\title{
REGIONALNE ZRÓŻNICOWANIE POZIOMU STAROŚCI I DYNAMIKI PROCESU STARZENIA SIE LUDNOŚCI KUBY W KONTEKŚCIE PRZEMIAN SPOÆECZNO-GOSPODARCZYCH
}

\author{
Mirosław Wójtowicz, Katarzyna Dembicz
}

\section{Regional differences in the level of ageing and the dynamics of the ageing process of the population of Cuba in the context of socio-economic changes}

\begin{abstract}
This article presents the origins and the impact of demographic and socio-economic factors on the process of demographic ageing of the population of Cuba. The main aim of the study was to show the dynamics and regional differences in population ageing based on the $\mathrm{W}_{\mathrm{SD}}$ dynamic ageing index as well as the $\mathrm{W}_{\mathrm{SE}}$ economic ageing index. It was shown that the ageing process reveals moderate diversity of the investigated phenomenon both in the urban-rural dimension as well as at the regional level. The process of population ageing is progressing throughout the whole country and its fastest pace was recorded in the outermost provinces. However, spatial differences in the ageing process may change fundamentally in the years to come, which will result from internal regulations concerning the mobility of the population, and new business investments. As a result, spatial differences are likely to increase and the spatial image of the ageing process will probably change.
\end{abstract}

Keywords: demographic structure, population ageing, Cuba

Zarys treści: W artykule przestawiono genezę procesu starzenia się ludności Kuby oraz wpływ, jaki wywarły na niego czynniki demograficzne i społeczno-ekonomiczne. Głównym celem badań było określenie dynamiki oraz regionalnych różnic w starzeniu się kubańskiego społeczeństwa w oparciu o wartości wskaźnika starzenia się demograficznego $\left(\mathrm{W}_{\mathrm{SD}}\right)$ i wskaźnika starzenia się ekonomicznego ludności $\left(\mathrm{W}_{\mathrm{SE}}\right)$. Stwierdzono, że proces starzenia się wykazuje umiarkowane zróżnicowanie zarówno w wymiarze miejsko-wiejskim, jak i w układzie regionalnym. Starzenie się społeczeństwa postępuje w całym kraju, a jego 
najszybsze tempo zanotowano w najbardziej peryferyjnych prowincjach. Jednakże różnice przestrzenne w poziomie starzenia się ludności mogą się zasadniczo zmienić w nadchodzących latach w wyniku wewnętrznych regulacji dotyczących mobilności ludności oraz nowych inwestycji. W rezultacie różnice przestrzenne mogą wzrosnąć, prowadząc równocześnie do zmian przestrzennego rozkładu procesu starzenia się ludności.

Stowa kluczowe: struktura demograficzna, demograficzne starzenie się społeczeństwa, Kuba

\section{Wprowadzenie}

Procesy demograficzne są silnie powiązane z gospodarką. Zarówno zachowania prokreacyjne ludności są ważną determinantą rozwoju ekonomicznego danego terytorium, jak i stan jego gospodarki może wpływać na procesy demograficzne (Okólski, Fihel 2012, 301-304). Europa zmaga się obecnie z niskimi wskaźnikami przyrostu naturalnego i starzejącym się społeczeństwem (Lesthaeghe 1991; Grundy 1996). Problem, który do tej pory był kojarzony wyłącznie z krajami wysoko rozwiniętymi (Andrews, Phillips 2005) dotyczy coraz szerszej grupy państw, w tym również latynoamerykańskich. Wśród nich na szczególną uwagę zasługuje Kuba (CEPAL 2009; Cotlear 2011).

Kraj ten w ciągu ostatnich kilkudziesięciu lat wzbudzał wiele zainteresowania w związku z jedyną zwycięską rewolucją socjalistyczną w tym regionie oraz realizowaną w jej następstwie polityką społeczno-gospodarczą. Obecnie ponownie zwraca uwagę świata, z jednej strony w związku z ogłoszonym w grudniu 2014 r. ociepleniem stosunków ze Stanami Zjednoczonymi, a z drugiej na skutek pogłębiającego się kryzysu demograficznego. Pomimo przyrostu naturalnego utrzymującego się w latach 1953-2014 od trzech dekad liczba ludności Kuby utrzymuje się na poziomie około $11 \mathrm{mln}$ mieszkańców, co wyraźnie odróżnia ją od innych państw Ameryki Łacińskiej. Obok znacznej emigracji, elementem, który przyczynia się do stagnacji liczby mieszkańców i malejącego przyrostu naturalnego, są zachowania prokreacyjne Kubańczyków. W ostatnich latach rząd kubański zaczął dostrzegać ten problem, nie tylko starając się poprawić warunki ekonomiczne i bytowe ludności, widząc w nich główną przyczynę spadku dzietności, ale również tworząc programy zachęcające młode małżeństwa do posiadania dzieci oraz przeciwdziałające wysokiej niepłodności par. Takie działania mają szczególne znaczenie, zważywszy na fakt, że w strategiach gospodarczych i programach rozwoju zaczęto uwzględniać mieszkańców jako ważnych aktorów transformacji (Dembicz 2013). Rząd Raula Castro, dzięki zbliżeniu ze Stanami Zjednoczonymi i nowym ustawom dotyczącym inwestycji zagranicznych, prawa podatkowego, rynku hurtowego, dzierżawy ziem uprawnych, nieruchomości i migracji, otwiera Kubę na zagraniczny kapitał. Jednocześnie te same prawa mają głębokie reperkusje lokalne. Dynamiczne starzenie 
się społeczeństwa kubańskiego oraz silna emigracja zmniejszają szanse powodzenia wprowadzanych reform. Brak kapitału społecznego bądź jego kurczące się zasoby, co obserwujemy w przypadku Kuby, są ważnym elementem utrudniającym, lub wręcz uniemożliwiającym, sukces transformacji społeczno-ekonomicznej, jaką kraj ten przechodzi współcześnie (Sztompka 1999).

$\mathrm{Z}$ tego powodu, zdaniem autorów artykułu, ważne jest szczegółowe zbadanie sytuacji demograficznej Kuby w ujęciu czasowym i przestrzennym w kontekście procesu starzenia się, mającego bezpośredni wpływ na rynek pracy, gospodarkę, sektor usług socjalnych i zdrowotnych. Główna hipoteza przyjęta do badań zakłada, że pomimo wdrażanej od 1959 r. polityki rządu oraz realizowanych strategii rozwojowych zmierzających do wyrównania różnic przestrzennych w poziomie rozwoju społeczno-ekonomicznego te nadal istnieją i ujawniają się szczególnie w sferze demograficznej. Hipotezy szczegółowe zakładają zaś, że:

- proces starzenia się społeczeństwa Kuby jest najsilniej zaawansowany w obszarach zurbanizowanych i lepiej rozwiniętych gospodarczo;

- obszary peryferyjne, cechujące się niższym poziomem urbanizacji i dominacją sektora rolnego w gospodarce, odnotowują niższy poziom starości demograficznej, ale ze względu na proces odpływu młodej ludności do prowincji bardziej rozwiniętych notują szybkie tempo starzenia się społeczeństwa.

Przeprowadzone badania mają na celu określenie zarówno stanu zaawansowania poziomu starości demograficznej, jak i zmian zachodzących w tym zakresie w latach 2005-2013. Wybrany przedział czasowy obejmuje okres, w którym zaczęto przeprowadzać reformy skutkujące obecnym otwarciem Kuby na świat. Istotnym celem analizy jest również zbadanie uwarunkowań procesu starzenia się ludności Kuby w możliwie najdłuższym przekroju czasowym, dlatego też w pierwszej części artykułu przedstawiono tło przemian demograficzno-społecznych, począwszy od lat 50. XX w. Od tego bowiem okresu dostępne są w miarę rzetelne dane statystyczne publikowane przez Narodowy Urząd Statystyczny - Oficina Nacional de Estadísticas (ONE). Przestrzenny zakres przeprowadzonych badań uwzględniał podział na 16 jednostek pierwszego szczebla podziału administracyjnego, w skład których wchodzi 15 prowincji i municypium specjalne Isla de la Juventud (ryc. 1) ${ }^{1}$. W procesie weryfikacji hipotez wykorzystano podstawowe mierniki procesu starzenia się, takie jak: wskaźniki starzenia się demograficznego i ekonomicznego oraz indeks starości demograficznej, których wartości zostały przeanalizowane z uwzględnieniem uwarunkowań historyczno-politycznych i społeczno-gospodarczych wpływających na przemiany kubańskiego społeczeństwa.

${ }^{1}$ W 2010 r. wprowadzono nowy podział administracyjny, w którym z prowincji La Habana utworzono dwie nowe: Artemisa i Mayabeque. 


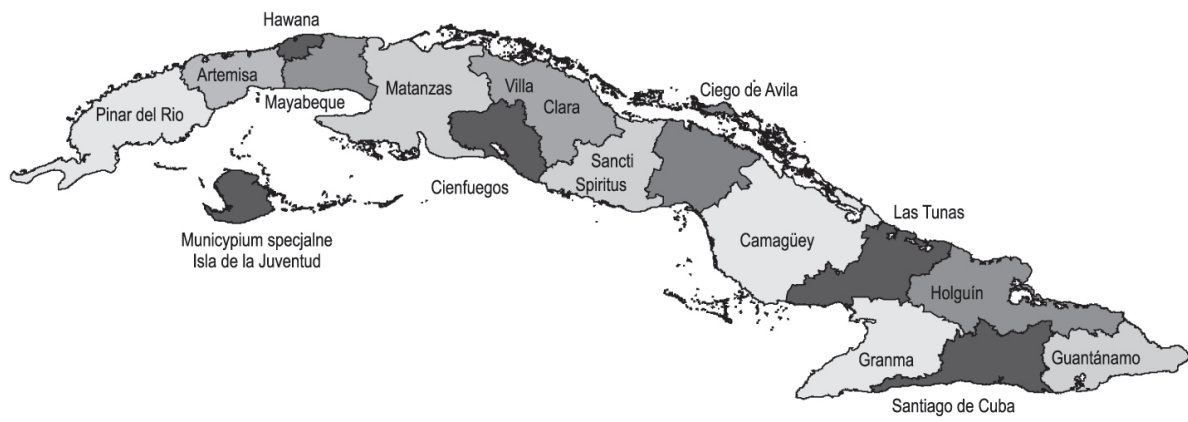

Ryc. 1. Podział administracyjny Kuby

Fig. 1. Administrative division of Cuba

Źródto: opracowanie własne na podstawie: Una mirada a Cuba (2010).

Source: own work based on: Una mirada a Cuba (2010).

\section{Uwarunkowania procesu starzenia się ludności Kuby}

Starzenie się społeczeństwa kubańskiego jest wynikiem zarówno spowolnienia przyrostu ludności młodej, jak i przyspieszenia wzrostu liczby ludności starszej. Relatywne zmniejszenie tempa przyrostu najmłodszych grup wiekowych jest wynikiem spadku poziomu płodności i rodności, co demografowie określają mianem „starzenia się od podstawy piramidy wieku”. Przyspieszenie wzrostu liczby osób starszych jest konsekwencją spadku umieralności w starszych grupach wieku i ten typ przemian nazywany jest „starzeniem się od wierzchołka piramidy”. Trzecim demograficznym czynnikiem starzenia się ludności są migracje. W świetle większości przeprowadzonych badań najliczniejszą grupę wśród migrantów stanowią ludzie młodzi, co sprawia, że obszary napływowe ulegają procesowi odmładzania populacji, natomiast regiony odpływowe charakteryzuje znaczne przyspieszenie procesu starzenia się. Znaczenie migracji jest szczególnie widoczne w układach lokalnych, gdzie przybierają one głównie postać przepływów między obszarami wiejskimi a miastami. Mogą też mieć znaczenie migracje międzynarodowe o charakterze długotrwałych, jednokierunkowych przepływów ludności napływającej do danego kraju lub go opuszczającej (Preston i in. 1989; Grundy 1996; Frątczak 2002; Kurek 2008).

W przypadku Kuby - oprócz wymienionych wyżej czynników kształtujących fenomen starzenia się - należy uwzględnić politykę państwa, która od połowy XX w. była ukierunkowana na poprawę jakości życia i zdrowia wszystkich obywateli wraz z zagwarantowaniem im powszechnej i bezpłatnej opieki zdrowotnej. Diametralnie zmieniła ona obowiązujący system polityczny i gospodarczy przyczyniając się do 
uwypuklenia niektórych zjawisk demograficznych. Skutkiem był spadek liczby zgonów (również wśród noworodków i dzieci do 5. roku życia) oraz zdecydowane wydłużenie się oczekiwanej długości życia. Jednocześnie w latach 60. XX w. podjęto działania zgodne z zaleceniami ONZ, a dotyczące wprowadzania polityk kontroli urodzeń. Ich rezultatem był powszechny dostęp na Kubie do podstawowych środków antykoncepcyjnych oraz zabiegów przerywania ciąży, które często stosowane są na wyspie jako jedna z metod planowania rodziny (Hollerbach 1980).

W latach 70. i 80. XX w. doszło do spadku, i tak niezbyt wysokiej na tle innych państw regionu, liczby urodzeń. Wiązało się to ze wspomnianymi wcześniej zmianami w polityce społeczno-gospodarczej po rewolucji. Silny nacisk kładła ona na aktywizację kobiet zarówno w sferze zawodowej, jak i edukacyjnej. Wprowadzono rozdział państwa od kościoła oraz otwartość światopoglądową. Ponadto przeważający w strukturze etnicznej społeczeństwa kubańskiego pierwiastek europejski, wpływał na stosunkowo szybkie przyjmowanie wzorców i modeli rodziny, typowych dla państw wyżej rozwiniętych (Hollerbach 1980; Díaz-Briquets, Pérez 1982; Modrzejewski 1987).

Rysujący się coraz wyraźniej kryzys demograficzny pogłębia silna emigracja, która trwała nieprzerwanie od roku 1959 do 2012². Doprowadziła ona do sytuacji, w której poza granicami kraju mieszkało w 2015 r. około 2,5 mln Kubańczyków, przede wszystkim w Stanach Zjednoczonych i Hiszpanii (Dembicz 2013; Hernández, Foladori 2014).

Wymienione wyżej czynniki doprowadziły do dynamicznie postępującego procesu starzenia się ludności Kuby, którego skutkiem jest bardzo wysoki udział osób powyżej 60. roku życia w ogólnej liczbie mieszkańców. Sytuacja jest szczególnie niekorzystna, gdyż notowana w ostatnich latach niska dzietność w połączeniu z liczną emigracją obejmującą przede wszystkim osoby w wieku produkcyjnym i reprodukcyjnym będzie pogłębiać niekorzystną sytuację demograficzną w przyszłości. Oba elementy stanowią nieodłączną część zjawisk zachodzących w trakcie procesów pierwszego i drugiego przejścia demograficznego (Okólski 1990; Lesthaeghe 1991; van de Kaa 2003). Procesy pierwszego przejścia demograficznego są szczególnie widoczne w demograficznej rzeczywistości Kuby od drugiej dekady XX w. (Hollerbach, Díaz-Briquets, Hill 1984; Alfonso Fraga 2006).

W latach 1920-1924 współczynnik urodzeń na wyspie spadł poniżej 40\%o i w kolejnych latach obniżał się stopniowo aż do roku 1958, poprzedzającego bezpośrednio wybuch rewolucji (Hollerbach 1980). Spadek natężenia urodzeń przy jednoczesnym nieznacznym obniżaniu się współczynnika zgonów prowadził do spadku odsetka dzieci przy równoczesnym zwiększaniu się udziału roczników starczych (ryc. 2).

\footnotetext{
${ }^{2}$ Chociaż była obecna już wcześniej (Dembicz 1969; Modrzejewski 1987).
} 


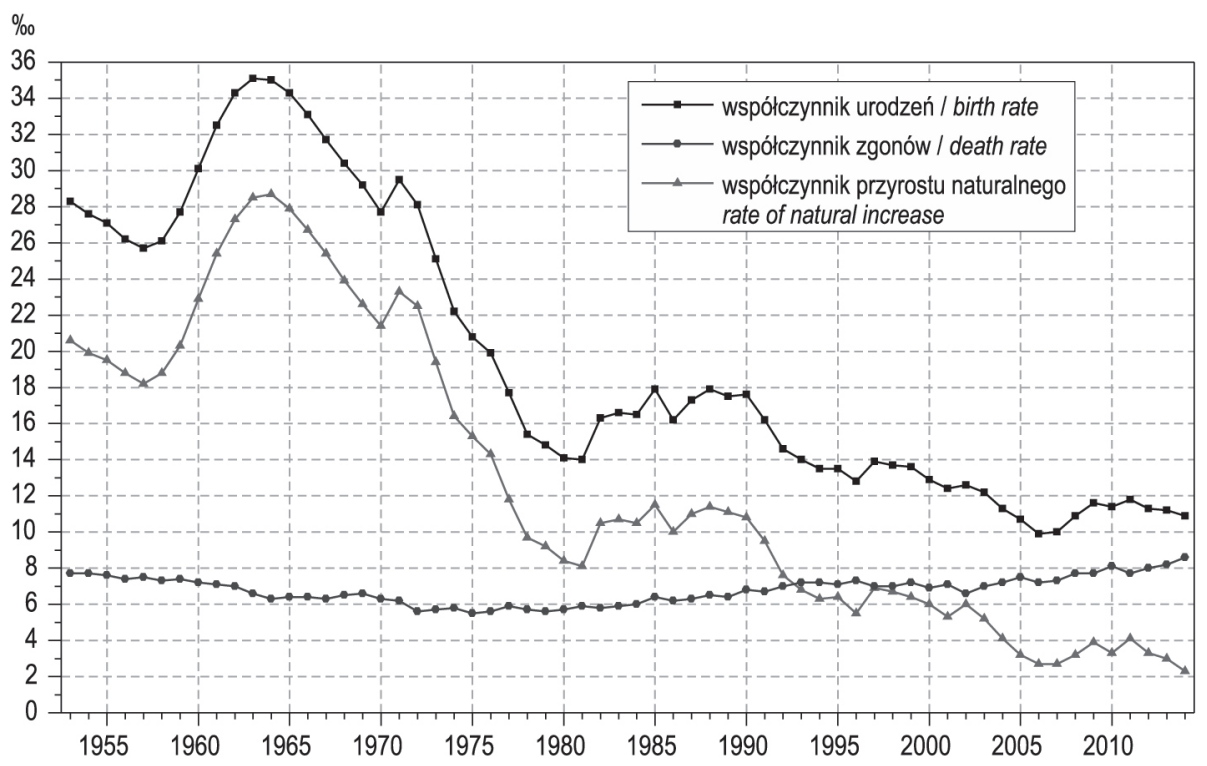

Ryc. 2. Zmiany wartości współczynników ruchu naturalnego ludności Kuby w latach 1953-2014

Fig. 2. Changes in the value of population movement coefficients of the population of Cuba in the years 1953-2014

Źródto: opracowanie własne na podstawie: Hollerbach i in. (1984: 14), Anuario Demográfico de Cuba 2013, 2014 oraz Anuario Estadístico de Salud 2014, 2015.

Source: own calculations based on: Hollerbach et al. (1984: 14), Anuario Demográfico de Cuba 2013, 2014 and Anuarío Estadistico de Salud 2014, 2015.

Tendencja do spadku liczby urodzeń została zahamowana w wyniku rewolucji kubańskiej. W latach 1959-1964, kraj ten wkroczył w okres baby boomu osiągającego swój szczyt w roku 1963 i 1964, kiedy współczynnik urodzeń przekroczył 35\%o (ryc. 2). Taki wzrost urodzeń był wywołany głównie wzrostem dzietności wśród młodszych kobiet. Świadczyć o tym może wzrost współczynnika płodności w grupie wiekowej 15-19 lat, który w latach 1950-1955 wynosił 73 urodzenia rocznie na 1000 kobiet, a w 1970 r. wzrósł do 110. Wzrost omawianego wskaźnika odnotowano także w pozostałych grupach wiekowych jednak nie był on aż tak znaczący. Tak znaczny przyrost urodzeń w okresie porewolucyjnym był wynikiem oddziaływania wielu czynników. $Z$ jednej strony przyczyniło się do niego zjawisko tzw. odroczenia urodzeń (postponing of births) w ostatnim okresie walk z dyktaturą prezydenta Batisty. Z drugiej - był on także związany z poprawą warunków bytowych 
i wzrostem realnych dochodów ludności po rewolucji, wynikających z nowej polityki zmierzającej do większej i sprawiedliwszej redystrybucji. W 1959 r. rząd kubański zniósł opłaty za czynsz i elektryczność, obniżył opłaty za komunikację i transport. Równolegle poszerzono dostęp do usług socjalnych, takich jak bezpłatna edukacja (w tym przedszkolna) i opieka medyczna. Na obszarach wiejskich pierwsza reforma rolna doprowadziła do nadania ziemi jej wcześniejszym dzierżawcom. W konsekwencji w bardzo krótkim czasie nastąpił wyraźny spadek realnych kosztów życia, szczególnie wśród najbiedniejszych grup ludności³ , co przełożyło się na poprawę nastrojów społecznych, wzrost wskaźnika małżeństw i w rezultacie wzrost liczby urodzeń (Hollerbach 1980: 100; Díaz-Briquets, Pérez 1982: 517-522).

Wśród innych czynników wpływających na wzrost płodności w okresie bezpośrednio następującym po zwycięstwie rewolucji kubańskiej wymienia się: restrykcje aborcyjne i ograniczenie dostępu do tego zabiegu na Kubie oraz zmniejszenie liczby środków antykoncepcyjnych dostępnych na rynku. Chociaż penalizacja aborcji obowiązywała od lat 80 . XIX w. ${ }^{4}$, nie była w rzeczywistości egzekwowana. Znajdowała jednocześnie dużą akceptację społeczną, stąd we wczesnej fazie tworzenia nowego państwa rząd rewolucyjny postanowił zmienić podejście. Zamknięcie prywatnych klinik lekarskich przeprowadzających aborcje, emigracja części personelu medycznego oraz nałożone embargo USA ograniczające mieszkańcom Kuby dostęp do importowanych produktów, w tym środków antykoncepcyjnych, odbiło się skokowym wzrostem stopy urodzeń (Hollerbach 1980: 100-101; Diaz-Briquets, Pérez 1982: 522-523).

Po okresie rewolucyjnego baby boomu Kuba wróciła na ścieżkę klasycznej transformacji demograficznej prowadzącej do dynamicznego spadku liczby urodzeń. W analizowanym okresie można wyróżnić cztery zasadnicze fazy zmniejszania się współczynnika urodzeń. Pierwsza, przypadająca na lata 1965-1972, charakteryzowała się stopniowym, umiarkowanym jego spadkiem z poziomu ok. $34 \%$ do $28 \%$. Druga faza (1972-1981) to okres gwałtownego załamania współczynnika urodzeń do poziomu zaledwie 14\%o. Kolejną - trzecią - fazę w latach 1982-1992 można określić mianem „echa porewolucyjnego wyżu demograficznego”. W jej trakcie doszło do odwrócenia tendencji spadkowej liczby urodzeń. Wartości współczynnika urodzeń w kolejnych latach wzrastają do 18\%o, aby w 1993 r. powrócić do poziomu z początku lat 80 . XX w. Rok ten wyznacza także początek ostatniej, czwartej, fazy przemian w ruchu naturalnym ludności, charakteryzującej się dalszym stopniowym spadkiem współczynnika urodzeń przy jednoczesnym wzroście wartości

\footnotetext{
${ }^{3}$ Obejmujących około $50 \%$ ludności kraju, zamieszkującej zarówno tereny wiejskie, jak i miejskie.

${ }^{4}$ Wprowadzono ją w 1879 r. na podstawie kodeksu karnego obowiązującego na Kubie i w Portoryko jako kolonii hiszpańskich, w 1936 r. prawo modyfikowano, dopuszczając usunięcie ciąży ze względu na zagrożenie życia matki, gwałt i możliwość wystąpienia chorób dziedzicznych.
} 
współczynnika zgonów. Malejąca różnica pomiędzy poziomem urodzeń i zgonów doprowadziła w konsekwencji do dalszego spadku współczynnika przyrostu naturalnego, który w 2014 r. osiągnął poziom nieznacznie przekraczający 2\%o (ryc. 2).

Obserwowany spadek przyrostu naturalnego był wynikiem postępującego spadku płodności. W 1964 r., wyznaczającym szczyt porewolucyjnego boomu demograficznego, ogólny współczynnik płodności wyniósł 164 urodzenia żywe na 1000 kobiet w wieku rozrodczym. W kolejnych latach podlegał stopniowemu spadkowi, który przybrał dynamiczne tempo w latach 70. XX w., osiągając poziom 60 urodzeń na 1000 kobiet w wieku rozrodczym w 1981 r. Dekada lat 80. XX w. była okresem nieznacznego wzrostu, a następnie stagnacji wartości omawianego współczynnika, natomiast w kolejnym dziesięcioleciu aż do początku XXI w. ulegał on dalszemu spadkowi, osiągając wartość 37 urodzeń żywych na 1000 kobiet w wieku rozrodczym w 2006 r. W kolejnych latach odnotowano jego nieznaczny wzrost i ustabilizowanie się wartości na poziomie 43-44 urodzenia żywe na 1000 kobiet w wieku rozrodczym (ryc. 3 ).

Zmiany tendencji prokreacyjnych na Kubie w latach 1953-2014 dobrze obrazuje współczynnik płodności całkowitej nazywany także współczynnikiem dzietności teoretycznej lub ogólnej (Total Fertility Rate - TFR) ${ }^{5}$. Wartości analizowanego współczynnika ulegały zmianom wynikającym z ogólnych przemian zachowań prokreacyjnych kubańskiego społeczeństwa. W pierwszej połowie XX w. jego wartość obniżyła się z 5,8 dziecka na kobietę w wieku rozrodczym (w świetle danych spisu ludności z 1907 r.) do 3,5 dziecka na kobietę w wieku rozrodczym według spisu z 1953 r. (Hollerbach 1980: 99).

W okresie porewolucyjnego baby boomu wartość omawianego współczynnika wzrosła do 4,7 dziecka na kobietę w wieku rozrodczym w 1964 r., by w kolejnych latach stopniowo maleć do wartości poniżej prostej zastępowalności pokoleń $(1,95)$ w 1978 r. Od końca lat 70. wartości współczynnika płodności całkowitej utrzymywały się poniżej poziomu zastępowalności pokoleń, osiągając najniższy poziom $(1,39)$ w 2006 r. (ryc. 3). Warto podkreślić, że od końca lat 70. XX w. niskie wartości współczynnika odegrały ważną rolę w przyspieszeniu tempa starzenia się ludności Kuby.

Zahamowanie wzrostu płodności po okresie porewolucyjnego baby boomu wynikało w dużej mierze z szybko postępujących procesów modernizacji społecznej związanych z wydłużeniem czasu edukacji kobiet, większą aktywizacją zawodową,

\footnotetext{
${ }^{5}$ Wyraża on średnią liczbę dzieci, jaką urodziłaby kobieta w ciągu okresu rozrodczego, przy założeniu niezmiennego wzorca płodności. Wartość tego miernika wynosząca ok. 2,1 gwarantuje prostą zastępowalność pokoleń. Spadek wartości tego współczynnika poniżej tego poziomu jest natomiast jednym z głównych wyznaczników początku drugiego przejścia demograficznego (van de Kaa 2003; Lesthaeghe 1991). Długotrwałe utrzymywanie się wartości tego miernika poniżej poziomu zastępowalności pokoleń prowadzi do przyspieszenia tempa starzenia się społeczeństwa, a dodatkowo, w sytuacji ujemnego salda migracji, nawet do depopulacji (Kurek 2008).
} 


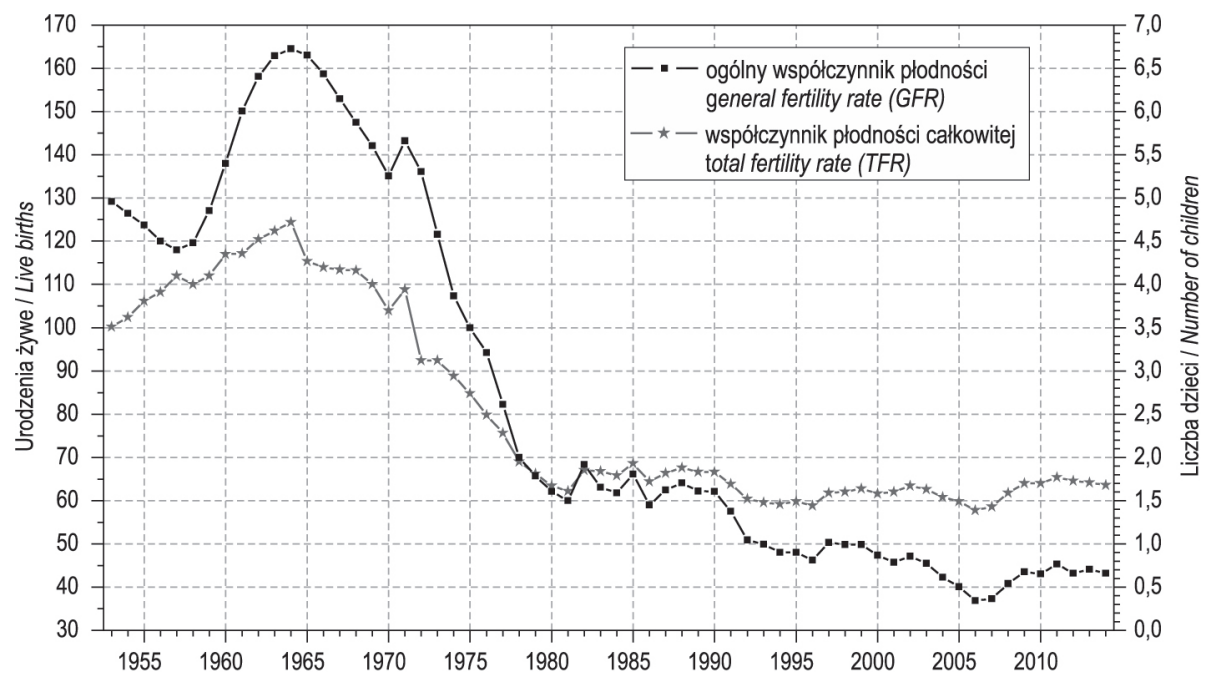

Ryc. 3. Zmiany wartości ogólnego współczynnika płodności oraz współczynnika płodności całkowitej ludności Kuby w latach 1953-2014*

Fig. 3. Changes in the value of the general fertility rate (GFR) and the total fertility rate (TFR) of population of Cuba in the years 1953-2014*

* w latach 1953-1982 w stosunku do kobiet w wieku 15-49 lat, dla danych z lat 1983-2014 w odniesieniu do kobiet w wieku 12-49 lat.

* in the years 1953-1982 in relation to women aged 15-49, for the data from 1983 to 2014 for women aged $12-49$ years.

Źródto: opracowanie własne na podstawie: Hollerbach i in. (1984: 14), Anuario Demográfico de Cuba 2013, 2014 oraz Anuario Estadístico de Salud 2014, 2015.

Source: own calculations based on: Hollerbach et al. (1984: 14), Anuario Demográfico de Cuba 2013, 2014 and Anuario Estadístico de Salud 2014, 2015.

postępującą urbanizacją ${ }^{6}$, a przede wszystkim w rezultacie zmian wzorców rodzinnych i zachowań prokreacyjnych oraz emancypacją kobiet. Ważną rolę odegrała także: depenalizacja aborcji, wprowadzona w roku 1961, stworzenie w 1965 r. ram prawnych do legalnego przeprowadzania zabiegów przerywania cięży w szpitalach oraz wprowadzenie w 1979 r. kar za zmuszanie do aborcji i jej przeprowadzanie w warunkach urągających zdrowiu i godności kobiety.

W wyniku liberalnego podejścia do przerywania ciąży, w sytuacji braku dostępu do innych metod kontroli urodzeń oraz przy stosunkowo dobrze rozwiniętej bezpłatnej i powszechnej opiece medycznej ta metoda ograniczania urodzeń często

\footnotetext{
${ }^{6} \mathrm{Na}$ warunki latynoamerykańskie i światowe wysokiej, bo sięgającej w 1970 r. $60 \%$, a w 1981 r. $69 \%$.
} 
okazywała się najprostsza dla kobiet, stąd jej gwałtowne rozpowszechnienie (Hollerbach 1980; Hollerbach i in. 1984; Alfonso Fraga 2006; Gran Alvarez, Lopez Nistal 2003; Gran Alvarez i in. 2013).

W latach 1968-1974 liczba legalnie przeprowadzonych aborcji wzrosła z ok. 28,5 tys. do ponad 131,5 tys. Warto jednak podkreślić, że wspólnie z nielegalnymi aborcjami łączną liczbę zabiegów sztucznego przerywania ciąży szacowano w tym roku na ponad 165,2 tys. (Hollerbach 1980: 102). Najwyższe wartości oficjalnie wykonanych aborcji, sięgające blisko 161 tys., zanotowano na Kubie w 1986 r., co sprawiło, że zbliżyły się one do ogólnej liczby urodzeń żywych, wynoszącej w tym roku ok. 166 tys., a wskaźnik liczby aborcji na 100 porodów osiągnął swoją rekordową wartość - 96,6. Z początkiem lat 90. XX w. liczba aborcji zaczęła maleć i w ostatnim okresie ustabilizowała się na poziomie nieznacznie przekraczającym 80 tys., przy liczbie urodzeń żywych nieznacznie przekraczającej 120 tys. rocznie. Nadal więc ten sposób kontroli urodzeń jest bardzo istotnym czynnikiem ograniczającym wielkość przyrostu naturalnego (ryc. 4).

Część badaczy wiąże gwałtowny spadek płodności zapoczątkowany z końcem lat 60. XX w. z niespełnionymi oczekiwaniami społecznymi rozbudzonymi po rewolucji. Początkowy optymizm i entuzjazm wywołany rewolucyjnymi zmianami w redystrybucji dochodów poprawiającymi jakość życia społeczeństwa zaczął stopniowo ustępować miejsca postępującemu pesymizmowi wynikającemu z narastających problemów ekonomicznych wzmagających się wraz z izolacją gospodarczą i polityczną kraju na arenie międzynarodowej. Do głównych czynników ograniczających płodność ludności zalicza się deficyt mieszkań utrudniający usamodzielnianie się młodym małżeństwom i powiększanie rodzin o seniorów wymagających opieki. Pogarszająca się sytuacja gospodarcza kraju, spadająca konsumpcja i niedobór podstawowych dóbr przy rosnących oczekiwaniach społecznych ludności, przekładały się na brak dostępu do podstawowych artykułów potrzebnych przy posiadaniu i wychowywaniu potomstwa, takich jak: artykuły dla niemowląt, przybory szkolne, ubrania, żywność dla dzieci. Wraz z rozwojem socjalistycznej gospodarki i państwa opiekuńczego gwarantującego w zasadzie całej populacji zatrudnienie i minimalne dochody, powszechną opiekę medyczną oraz emerytury, dzieci przestały być kluczowym źródłem socjalno-ekonomicznego zabezpieczenia na starość (Díaz-Briquets, Pérez 1982: 523-533).

Zmiany polityczne, z którymi nie wszyscy się utożsamiali, oraz pogłębiający się kryzys gospodarczy stały się głównymi czynnikami wypychającymi (push factors), skłaniającymi mieszkańców wyspy do emigracji. Odpływ migracyjny należy uznać, w przypadku Kuby, za czynnik ograniczający tempo wzrostu ludności i przyspieszający starzenie się społeczeństwa. W latach 1959-2013 ujemne saldo migracji było nieodłącznym elementem krajobrazu demograficznego kraju i w świetle oficjalnych statystyk wyniosło ponad 1,5 mln osób. Do końca lat 80. XX w. dominowała przede 


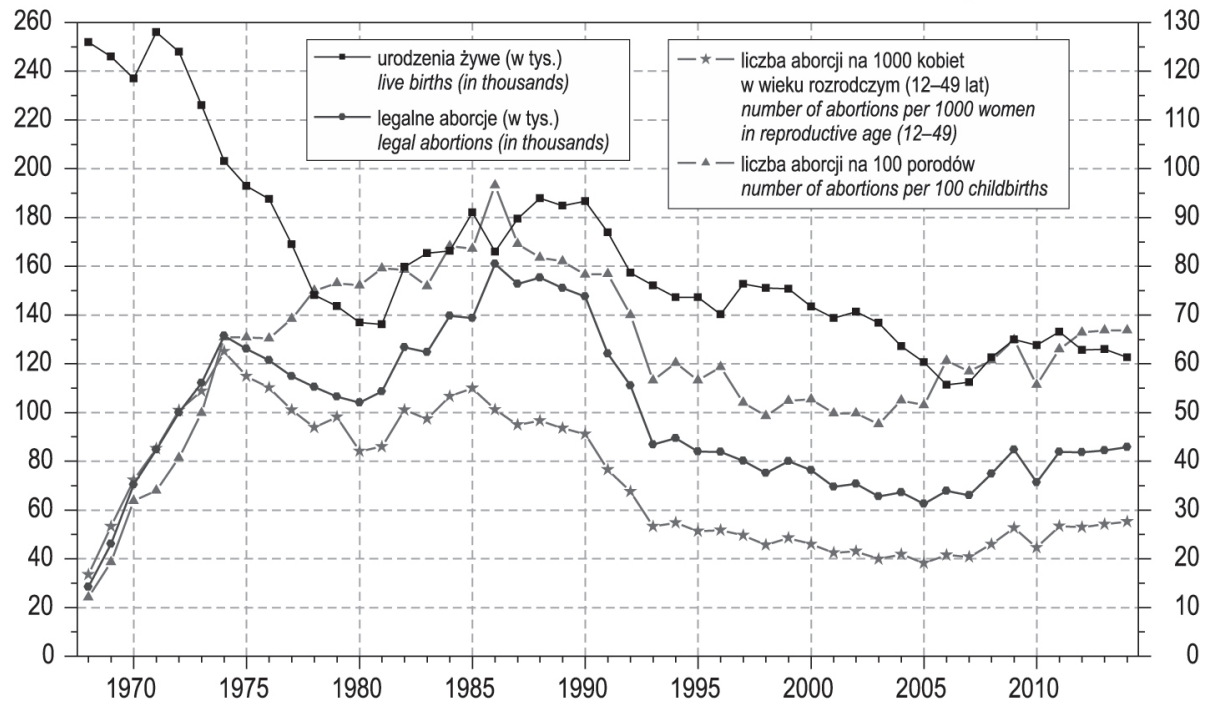

Ryc. 4. Zmiany liczby urodzeń żywych i aborcji oraz wskaźników aborcji ludności Kuby w latach 1968-2014

Fig. 4. Changes in the number of live births, abortions and abortion rates of the population of Cuba in the years 1968-2014

Źródto: opracowanie własne na podstawie: Hollerbach i in. (1984: 14), Anuario Demográfico de Cuba 2013, 2014 oraz Anuarío Estadístico de Salud 2014, 2015.

Source: own calculations based on: Hollerbach et al. (1984: 14), Anuario Demográfico de Cuba 2013, 2014 and Anuario Estadístico de Salud 2014, 2015.

wszystkim emigracja o charakterze uchodźctwa politycznego. Lata 1959-1989 to okres od zwycięstwa rewolucji aż do rozpadu bloku wschodniego, wspierającego ekonomicznie i politycznie kubański rząd. W gospodarce wyspy, pomimo wprowadzonego embarga przez USA, to czas względnej stabilności, ogólnej poprawy jakości życia, poziomu edukacji i opieki medycznej, pełnego zatrudnienia i wydłużenia przewidywanej długości życia. Po tym okresie emigracja wzbogaciła się o pierwiastek ekonomiczny, który nasila się z czasem i trwa do chwili obecnej. Wiąże się ona z upadkiem Związku Radzieckiego i demokratyzacją innych państw dawnego bloku socjalistycznego. Dla Kuby wiązało się to z utratą dostaw ropy naftowej ze ZSRR oraz zaprzestaniem wymiany handlowej z państwami RWPG. Dodatkowo zbiegło się ze światowym załamaniem cen cukru, który był jednym z głównych towarów eksportowych oraz zaostrzeniem embarga USA wobec wyspy po 1992 r. Połączenie wymienionych czynników ekonomicznych i politycznych przyczyniło się do zapaści 
gospodarki kubańskiej, co stało się kolejnym czynnikiem wypychającym nową falę migrantów wyjeżdżających z kraju. Ta fala emigracyjna objęła szersze spektrum społeczne zarówno pod względem wykształcenia, jak i pochodzenia, a migrujący częściej wskazywali motywy ekonomiczne oraz społeczne (łączenie rodzin) jako powody wyjazdu (Hernández, Foladori 2014: 28-29).

Momentem zwrotnym w dotychczasowej tendencji był 2013 r. Wprowadzone zmiany w kubańskim prawie migracyjnym, ułatwiające Kubańczykom wyjazdy, jak i przyjazdy osobom na stałe mieszkającym za granicą, zaburzyły dotychczasowe trendy ruchu migracyjnego, wzbogacając go o grupę migrantów czasowych, do tej pory w niewielkim stopniu występujących w rzeczywistości społecznej i ekonomicznej Kuby. Według danych oficjalnych Narodowego Urzędu Statystycznego po raz pierwszy w historii współczesnej Kuby odnotowano dodatnie wartości salda migracji wynoszące 3,3 tys. osób, co wskazywać może na próbę przełamania długotrwałego trendu dominacji wyjazdów z tego kraju. Dane te należy jednak ostrożnie interpretować, biorąc pod uwagę obowiązujące na Kubie prawo, które nie uznaje podwójnego obywatelstwa. Wielu z wjeżdżających na teren kraju obywateli (zmuszanych w celu wjazdu do posługiwania się kubańskim paszportem) posiada jednak także drugie obywatelstwo. Na tej podstawie można sądzić, że przedstawione statystyki zniekształcają demograficzną rzeczywistość na wyspie. Warto zwrócić uwagę, że w ostatnich dekadach ujemne saldo migracji utrzymywało się na poziomie znacznie wyższym niż na przełomie lat. 80. i 90. XX w. Szczególnie wysokie wartości osiągnęło w 1994 r. w trakcie tzw. kryzysu balseros, czyli uciekinierów na tratwach (rafters crisis), kiedy to przekroczyło wartość 47,8 tys. osób. Łącznie w latach 1994-2012 saldo migracji wyniosło - 637,5 tys. osób (ryc. 5).

Na przełomie XX i XXI w. uległa zmianie struktura emigrantów kubańskich, wśród których dominują osoby w grupie wiekowej 20-40 lat, dobrze wykształcone, mobilne i aktywne zawodowo, co pogłębia problemy ekonomiczne kraju. Ubytek tej grupy wiekowej ludności przyczynia się także do przyspieszenia procesu starzenia się społeczeństwa wyspy. Osoby wyjeżdżające, będące w większości w wieku reprodukcyjnym, przyczyniały się do przyspieszenia spadku przyrostu naturalnego. Dodatkowym ważnym czynnikiem wpływającym na dalsze tendencje prokreacyjne jest coraz silniejsza feminizacja migracji, zgodna z regionalnymi i światowymi tendencjami. Od 1995 r. kobiety stanowią ponad połowę wszystkich emigrujących z kraju, co uszczupla zasoby osób odpowiedzialnych za wielkość przyszłego przyrostu naturalnego (Hernández, Foladori 2014: 32-34).

Ważnym czynnikiem przyspieszającym starzenie się społeczeństwa kubańskiego jest wzrost liczy osób starszych, czyli tzw. starzenie się od wierzchołka piramidy. Jest ono konsekwencją spadku umieralności w starszych grupach wieku oraz wydłużania się przeciętnej długości trwania życia. Proces ten jest również związany z modernizacją społeczną oraz postępem w dziedzinie higieny i ochrony zdrowia. Poprawa 


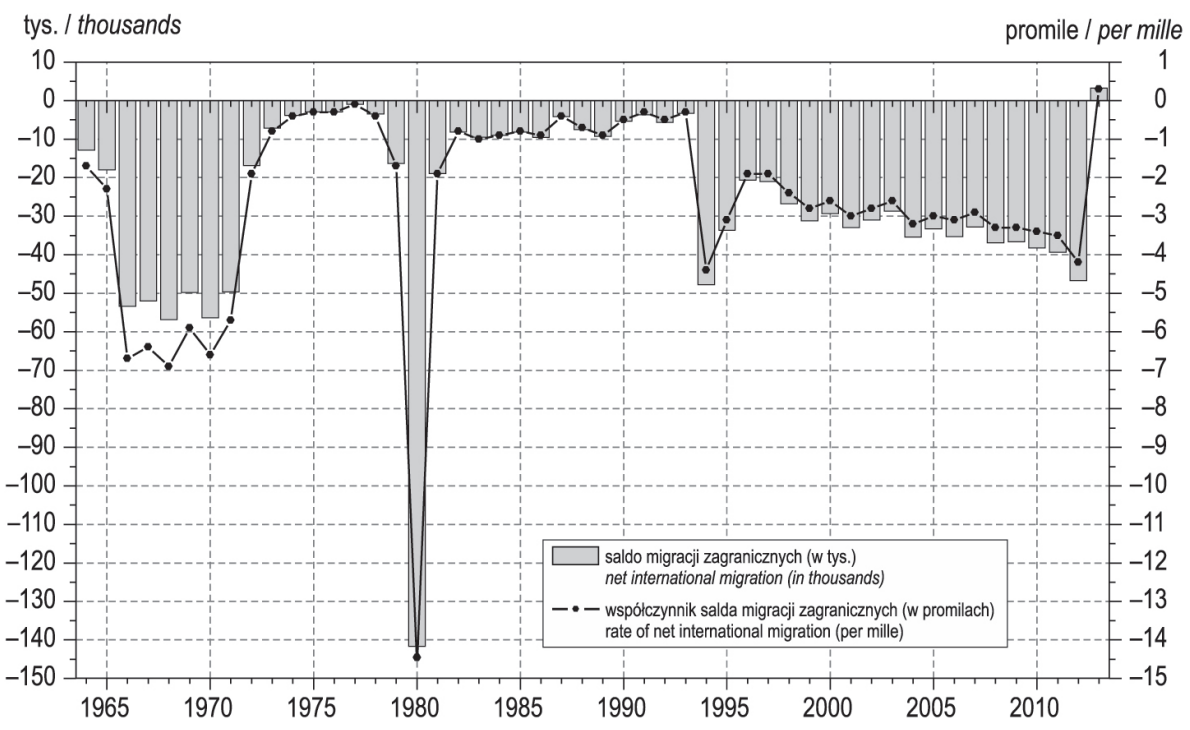

Ryc. 5. Zmiany wielkości salda migracji zagranicznych ludności Kuby, w latach 1964-2013 Fig. 5. Changes in the value of net international migration of the population of Cuba in the years 1964-2013

Źródto: opracowanie własne na podstawie: Anuario Demográfico de Cuba 2013, 2014. Source: own calculations based on: Anuario Demográfico de Cuba 2013, 2014.

warunków życia szczególnie szybko uwidacznia się wraz z postępami procesu urbanizacji, a Kuba jest jednym z najsilniej zurbanizowanych krajów w regionie. Posiada także długie tradycje miejskie. Już w świetle spisu ludności z 1907 r. blisko 44\% mieszkańców kraju stanowiła ludność miejska. Do 1953 r. poziom urbanizacji wzrósł do 57\%, a w 1970 r. przekroczył 60\% (Modrzejewski 1987: 71-81). W 2013 r. wyniósł zaś blisko 77\% (Panorama Teritorial. Cuba 2014).

Kraj ten posiadał również, w okresie przedrewolucyjnym, stosunkowo dobrze rozwiniętą opiekę medyczną, która uległa dalszej poprawie i upowszechnieniu dostępu w okresie porewolucyjnym. Znalazło to odzwierciedlenie w wartościach wskaźnika przewidywanej długości życia. W połowie lat 50. XX w. przewidywana długość życia na Kubie przekraczała 62 lata. W okresie porewolucyjnym zaczęła się dynamicznie wydłużać, osiągając na przełomie lat 60. i $70 \mathrm{XX}$ w. ponad 70 lat, a na początku drugiej dekady XXI w. przekroczyła 78 lat, dla obu płci. Szczególnie wysokie wartości odnotowano w przypadku kobiet, dla których przewidywana długość życia w 2013 r. przekraczała 80 lat i była o niecałe 4 lata dłuższa niż w przypadku mężczyzn (tab. 1). 
Tab. 1. Zmiany przewidywanej długości życia ludności Kuby, w latach 1952-2013

Table 1. Changes in life expectancy of the population of Cuba in the years 1952-2013

\begin{tabular}{|c|c|c|c|c|}
\hline $\begin{array}{c}\text { Okres/ } \\
\text { Period }\end{array}$ & $\begin{array}{c}\text { Ogółem/ } \\
\text { Total }\end{array}$ & $\begin{array}{c}\text { Mężczyźni (M)/ } \\
\text { Males (M) }\end{array}$ & $\begin{array}{c}\text { Kobiety (K)/ } \\
\text { Females (F) }\end{array}$ & $\begin{array}{c}\text { Różnica (K-M)/ } \\
\text { Difference (F-M) }\end{array}$ \\
\hline $1952-1954$ & 62,29 & 60,22 & 64,11 & 3,89 \\
\hline $1969-1971$ & 70,04 & 68,55 & 71,82 & 3,27 \\
\hline $1977-1978$ & 73,03 & 71,45 & 74,91 & 3,46 \\
\hline $1980-1981$ & 73,55 & 71,92 & 75,35 & 3,43 \\
\hline $1983-1984$ & 74,27 & 72,66 & 76,10 & 3,44 \\
\hline $1986-1987$ & 74,46 & 72,74 & 76,34 & 3,60 \\
\hline $1988-1989$ & 74,75 & 72,89 & 76,80 & 3,91 \\
\hline $1990-1991$ & 74,70 & 72,93 & 76,58 & 3,65 \\
\hline $1994-1995$ & 74,83 & 72,94 & 76,90 & 3,96 \\
\hline $1998-2000$ & 76,15 & 74,20 & 78,23 & 4,03 \\
\hline $2001-2003$ & 77,00 & 75,13 & 78,97 & 3,84 \\
\hline $2005-2007$ & 77,97 & 76,00 & 80,02 & 4,02 \\
\hline $2011-2013$ & 78,46 & 76,50 & 80,45 & 3,95 \\
\hline
\end{tabular}

Źródto: opracowanie własne na podstawie: Mujeres cubanas en edad fértil... 2011; Anuario Demográfico de Cuba 2013, 2014.

Source: own calculations based on: Mujeres cubanas en edad fértil... 2011; Anuario Demográfico de Cuba 2013, 2014.

Warto podkreślić, że biorąc pod uwagę powyższy wskaźnik, wartości, jakie osiąga Kuba, są porównywalne, a często nawet nieznacznie wyższe niż notowane w wielu państwach o znacznie wyższym poziomie rozwoju społeczno-ekonomicznego, zaliczanych do grona krajów wysoko rozwiniętych (Cotlear 2011).

Kuba już z końcem XX w. przestała charakteryzować się młodą strukturą wiekową społeczeństwa. W 1970 r. współczynnik starości demograficznej wyniósł nieco ponad 9\%, w 1990 r. - 12\%, a dla 2010 r. było to już ponad 17\%. Jeszcze wyraźniej tę dynamikę widać, gdy obserwuje się zmiany w udziale osób powyżej 60. roku życia w ogólnej liczbie mieszkańców kraju (ryc. 6). Na uwagę zasługuje również fakt, iż prognozy demograficzne zakładają, że w 2030 r. udział ludności w wieku powyżej 60 lat przekroczy 30\% ogółu mieszkańców kraju.

Wzrostowi odsetka ludności starej towarzyszy także zwiększająca się średnia wieku społeczeństwa. W 1950 r. wynosiła ona 22,3 lat, w 1990 - 27,7, a w 2010 - 38,5. Warto podkreślić, że zaznaczała się wyraźna różnica między obu płciami. W 2010 r. Średnia wieku mężczyzn wynosiła 37,7 lat, podczas gdy kobiet sięga aż 39,1 lat. Prognozy kubańskiego urzędu statystycznego zakładały, że w 2014 r. przekroczy ona 41 lat. Zaznaczają się również znaczące różnice przestrzenne średniej wieku społeczeństwa kubańskiego. W 2010 r. statystycznie „najstarsi” byli mieszkańcy Hawany (średnia wieku 40,2 lat) i prowincji Villa Clara (40,4 lat), a „najmłodsi” 


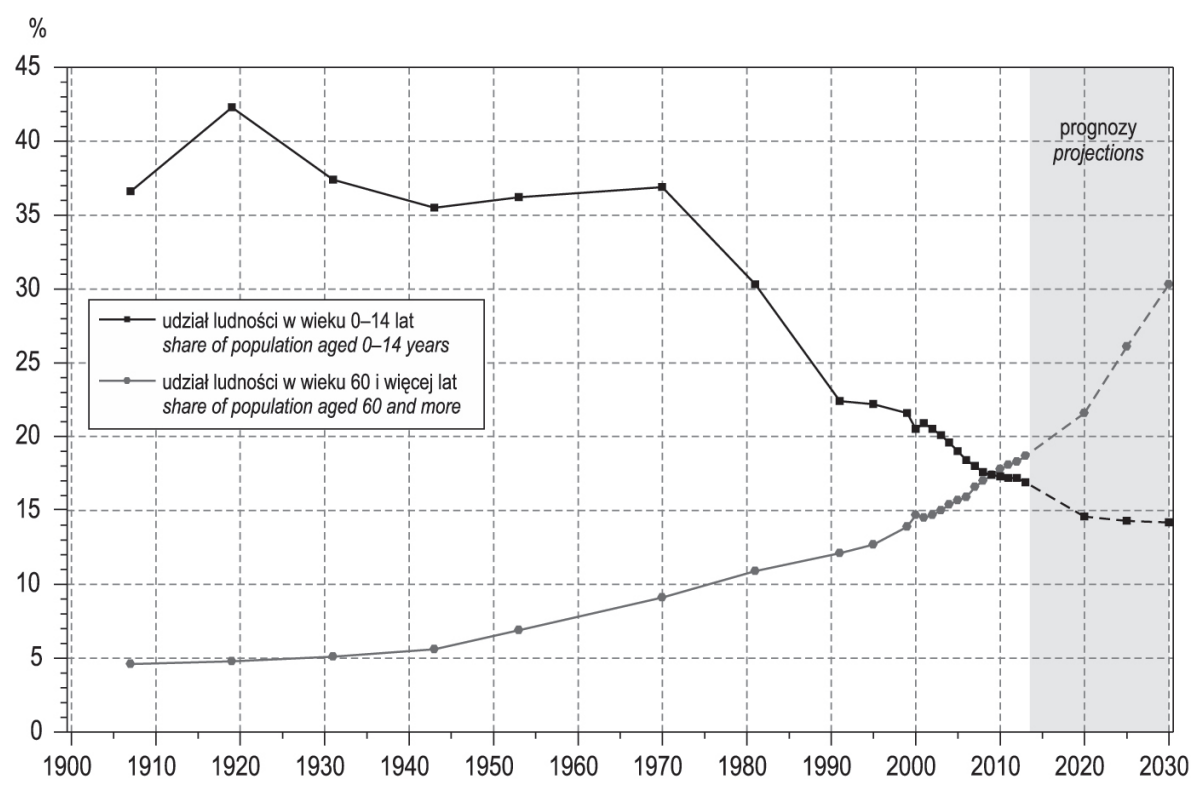

Ryc. 6. Zmiany udziału dzieci i ludności starszej w populacji Kuby w latach 1907-2030

Fig. 6. Changes in the share of children and elderly people in the population of Cuba in the years 1907-2030

Źródto: opracowanie własne na podstawie: Anuario Demográfico de Cuba 2013, 2014.

Source: own calculations based on: Anuario Demográfico de Cuba 2013, 2014.

mieszkańcy prowincji Guantanamo (35,4 lat) i wyspy Isla de la Juventud (36,3 lat) (Anuario Demografico de Cuba 2010, 2011).

Podsumowując przedstawione wyżej zmiany w czasie uwarunkowań procesu starzenia się społeczeństwa Kuby, warto podkreślić, że wywołujące go czynniki demograficzne prowadzą zarówno do starzenia się , od podstawy”, jak i , od wierzchołka piramidy". $Z$ jednej strony gwałtownie zmalało tempo przyrostu naturalnego oraz wskaźniki płodności, przy jednoczesnym trwałym ubytku migracyjnym ludności. Z drugiej natomiast - wydłużyło się przeciętne trwanie życia ludzkiego, co sprzyjało znaczącemu wzrostowi udziału najstarszych grup wiekowych w strukturze ludności Kuby. Przykładowo, dla osób powyżej 60 lat oczekiwana długość życia wynosi obecnie, dla obu płci, około 23 lat. Jednocześnie, udział osób powyżej 80. roku życia w społeczeństwie kubańskim wyniósł w 2014 r. aż 3,6\%, czyli prawie 400 tys. osób (Anuario Demografico de Cuba 2014, 2015). 


\section{Przestrzenne zróżnicowanie poziomu starości}

Heterogeniczność Kuby przejawia się równocześnie w przestrzeni ekonomicznej, społecznej i kulturowej. Jednym z kształtujących ją elementów jest czynnik historyczny, ale przede wszystkim rozwijana w XVIII i XIX w. gospodarka plantacyjna trzciny cukrowej i tytoniu. Obrazowo pisze o tym Fernando Ortíz w dziele El contrapunteo Cubano del tabaco y el azúcar: Træcina cukrowa i tytoń róśniq się między sobq diametralnie. Tworzac gtębokie kontrasty w kubańskiej gospodarce, w rolnictwie, produkcji $i$ w wymiarze lud:kim. (... intensywne uprawy versus uprawy ekstensywne, praca niewielu $i$ sadania dla mas, imigracja biatych $i$ więzienie Caarnych, wolność i niewolnictwo. (...) tytoń zwiqzany jest : miastem a cukier z obszarami wiejskimi (Ortiz 1973: 21).

Treść cytatu może stanowić przesłankę do dalszych rozważań i prób wytłumaczenia stanu przestrzennego zróżnicowania wyspy, w tym interesującego nas poziomu starości jej mieszkańców, na który wpływ miały również decyzje polityczne reżimu Fidela Castro.

Rozwój uprawy trzciny cukrowej i tytoniu przyczynił się do podziału Kuby pod względem gospodarczo-społecznym. W zachodniej części (obecnie prowincje Pinar del Río i Artemisa), gdzie dominowała (i nadal przeważa) produkcja tytoniu, koncentrowała się ludność pochodzenia europejskiego, propagująca katolickie tradycje rodzinne. $Z$ kolei plantacje trzciny cukrowej, rozwijające się dynamicznie w części centralnej i wschodniej kraju, powodowały najpierw napływ niewolniczej siły z Afryki, a po abolicji również Czarnych imigrantów z sąsiednich wysp Haiti i Jamajka. Taka sytuacja ukształtowała wyraźny podział pogłębiany działaniami władz, w tym polityką rozwoju infrastruktury i szkolnictwa, faworyzującą rozwój Hawany oraz centralnej części Kuby. Prowadziło to do ekonomicznej, kulturowej i edukacyjnej marginalizacji wschodniej części kraju, uważanej często przez rządzących i elity społeczne za „gorszą” i bardziej zacofaną. To właśnie w tej części Kuby rodziły się ruchy niepodległościowe i rewolucje społeczne, także ta ostatnia z 1959 r. (Dembicz 1969; Modrzejewski 1987).

Pomimo znacznych dysproporcji społecznych i ekonomicznych, w pierwszej połowie XX w. Kuba była jednym z najlepiej rozwiniętych pod względem ekonomicznym państw Ameryki Łacińskiej, co znajdowało odzwierciedlenie w urbanizacji kraju. W 1953 r. Kubańczycy byli jednym z najbardziej miejskich społeczeństw Ameryki Łacińskiej, z 57\% osób żyjących w jedynie 22 miastach. Najsłabiej zurbanizowane obszary zlokalizowane były na dwóch przeciwległych krańcach wyspy, na wschodzie - dzisiejsze prowincje Holguín, Las Tunas, Granma, Guantánamo, i na zachodzie - Pinar del Río, Artemisa, gdzie stopień urbanizacji wahał się między $25 \%$ a $40 \%$. Najwięcej miast skoncentrowanych było w zachodniej i centralnej części kraju, które tętniły życiem gospodarczym, kulturalnym i naukowym, tworząc dzięki produkcji cukru oraz artykułów pochodzenia zwierzęcego znaczną część 
PNB Kuby. W tej części kraju rozpoczął się również dynamiczny rozwój turystyki, na przełomie lat 30. i 40. XX w., pogłębiając dysproporcje między wsią a miastem (Dembicz 1969; Modrzejewski 1987).

Poziom urbanizacji i rozwoju gospodarczego, w tym zamożności społeczeństwa, stopień alfabetyzacji oraz poziom higieny, są determinantami, które legły u podstaw rozwoju sytuacji demograficznej Kuby w drugiej połowie XX w. - okresu naznaczonego głębokimi przemianami politycznymi, ekonomicznymi i społecznymi zmierzającymi do wyrównywania różnic społecznych i zapewnienia dobrobytu wszystkim obywatelom poprzez powszechny dostęp do edukacji, służby zdrowia oraz rynku pracy. Zmiany wprowadzone przez rząd rewolucyjny, który świadomie wspierał rozwój terenów peryferyjnych, doprowadziły do ilościowego rozwoju miast, wzmocnienia roli średnich i małych ośrodków miejskich w sieci osadniczej kraju (Landstreet, Mundigo 1983; Díaz-Briquets, Pérez 1982).

W 1970 r. na Kubie funkcjonowały już 32 miasta, w 1981 - 42, a w 2002 r. - 57, chociaż nie towarzyszył temu zdecydowany wzrost ludności miejskiej. Wartości wskaźnika urbanizacji zwiększyły się z 60\% w 1970 r. do $69 \%$ w 1981 i blisko 77\% w 2013 r. Pomimo wysiłków zmierzających do niwelowania regionalnych różnic w poziomie urbanizacji pozostają one nadal widoczne. Prowincje Pinar del Rio i Artemisa w zachodniej części Kuby, notujące w 2013 r. wskaźnik urbanizacji odpowiednio: $64,6 \%$ i 70,4\% pozostają relatywnie słabo zurbanizowane na tle średniej dla kraju. Podobną sytuację obserwujemy również w przypadku wymienionych wcześniej wschodnich prowincji: Granma, Guantánamo, Las Tunas, Holguín, których poziom urbanizacji pozostaje znacząco niższy na tle średniej krajowej (tab. 2). Obszary o zdecydowanie rolniczym charakterze i słabo zurbanizowane obejmują dwie wymienione wyżej prowincje leżące w zachodniej części kraju oraz cztery położone na wschodzie. Obszary o bardzo wysokim stopniu urbanizacji, gdzie koncentrują się najważniejsze ośrodki miejskie i przemysłowe, zajmują zaś centralną oraz częściowo zachodnią Kubę (Iñiguez i in. 2013).

Słabiej zurbanizowane, peryferyjne prowincje, cechujące się zarazem niższym poziomem rozwoju społeczno-gospodarczego, odnotowują także stosunkowo wysokie ujemne saldo migracji wewnętrznych (np. Guantanamo - 7\%o, Granma - 6\%o). Odpływająca z nich ludność przenosi się głównie Hawany oraz prowincji leżących w centralnej części wyspy i charakteryzujących się wyższym poziomem urbanizacji i rozwoju gospodarczego, takich jak: Matanzas, Mayabeque, Cienfuegos czy Ciego de Avila (tab. 2). Różnice przestrzenne w poziomie urbanizacji i rozwoju społeczno-gospodarczym wywołujące obserwowane w ostatnich latach wewnętrzne przepływy migracyjne znajdują także odzwierciedlenie w poziomie oraz tempie procesu starzenia się ludności, co zostanie szerzej przedstawione w dalszej części artykułu. 
Tab. 2. Kuba: stopień urbanizacji, saldo migracji wewnętrznych i zagranicznych 2009-2013 Table 2. Cuba: level of urbanization, internal and international net migration rates in the years 2009-2013

\begin{tabular}{|c|c|c|c|c|c|}
\hline \multirow{3}{*}{$\begin{array}{l}\text { Prowincje/ } \\
\text { Provinces }\end{array}$} & \multirow{3}{*}{$\begin{array}{c}\begin{array}{c}\text { Stopień urbanizacji/ } \\
\text { Level of urbanization }\end{array} \\
{[\%]} \\
2013\end{array}$} & \multicolumn{2}{|c|}{$\begin{array}{l}\text { Saldo migracji wewnętrznych/ } \\
\text { Internal net migration rate }\end{array}$} & \multicolumn{2}{|c|}{$\begin{array}{l}\text { Saldo migracji zagranicznych/ } \\
\text { International net migration rate }\end{array}$} \\
\hline & & \multicolumn{4}{|c|}{$[\% \circ]$} \\
\hline & & 2009 & 2013 & 2009 & 2013 \\
\hline Pinar del Río & 64,6 & $-2,3$ & $-1,5$ & $-3,0$ & 0,2 \\
\hline Artemisa & 70,4 & 4,9 & 3,0 & $-4,1$ & 0,0 \\
\hline La Habana & 100,0 & 5,1 & 5,2 & $-7,8$ & 0,8 \\
\hline Mayabeque & 73,5 & 4,1 & 2,0 & $-3,7$ & 0,0 \\
\hline Matanzas & 83,3 & 4,7 & 4,1 & $-2,6$ & 0,2 \\
\hline Villa Clara & 77,9 & $-1,4$ & $-0,4$ & $-3,6$ & 0,2 \\
\hline Cienfuegos & 82,0 & 3,3 & 0,9 & $-2,4$ & 0,3 \\
\hline Sancti Spiritus & 72,6 & $-0,2$ & 0,6 & $-2,0$ & 0,3 \\
\hline Ciego de Avila & 73,6 & 2,8 & 2,1 & $-2,0$ & 0,0 \\
\hline Camaguey & 78,0 & $-2,9$ & $-1,4$ & $-2,8$ & 0,5 \\
\hline Las Tunas & 65,6 & $-1,6$ & $-2,0$ & $-1,2$ & 0,2 \\
\hline Holguín & 66,2 & $-3,7$ & $-3,3$ & $-1,6$ & 0,1 \\
\hline Granma & 61,3 & $-3,6$ & $-6,0$ & $-0,6$ & 0,0 \\
\hline Santiago de Cuba & 71,1 & $-4,1$ & $-2,7$ & $-1,5$ & 0,3 \\
\hline Guantánamo & 63,7 & $-7,0$ & $-7,0$ & $-0,9$ & 0,1 \\
\hline Isla de la Juventud & 82,4 & $-2,2$ & $-5,3$ & $-2,3$ & $-0,1$ \\
\hline Kuba & 76,8 & - & - & $-3,3$ & 0,3 \\
\hline
\end{tabular}

Źródto: Panorama Territorial. Cuba (2014), ONE. www.one.cu.

Source: Panorama Territorial. Cuba (2014), ONE. www.one.cu.

Niewielki wzrost ludności miejskiej w porównaniu z szybkim wzrostem liczby miast można tłumaczyć zmianami demograficznymi przedstawionymi wcześniej, w tym zdecydowanym spadkiem przyrostu naturalnego oraz wysoką emigracją zagraniczną dotyczącą szczególnie ludności pochodzenia europejskiego. Regulacje rządu limitujące przepływy ludności wewnątrz kraju, w tym te wprowadzone w 1997 r., były dodatkową barierą mobilności do stolicy, a także hamowały rozwój innych większych miast ${ }^{7}$. W okresie 1980-2000 głównymi kierunkami migracji wewnętrznych na Kubie były dwa najważniejsze miasta Hawana i Santiago de Cuba (Dembicz 2013).

\footnotetext{
${ }^{7}$ Po upadku bloku socjalistycznego, w czasie tzw. Período Especial (1990-1995) Hawana przeżyła napływ niekontrolowany ludności z mniejszych miejscowości, w których ich mieszkańcy pozbawieni zostali środków do życia ze względu na głęboki kryzys zaopatrzeniowy. Rząd Kuby, aby ograniczyć falę migrantów, wprowadził dekret nr 217 (22 kwietnia 1997 r.) wymagający uzyskania przez obywateli zezwoleń celem osiedlenia się w Hawanie (Iñiguez i in. 2013).
} 
Miasta charakteryzujące się wyższym niż na wsi poziomem higieny, łatwiejszym dostępem do służby zdrowia i szkolnictwa, gdzie dominuje indywidualny styl życia, a cele osobiste jednostki przeważają nad kolektywnymi, są obszarami, na których proces starzenia się demograficznego może następować znacznie dynamiczniej niż na pozostałych terenach. Znalazło to swoje odzwierciedlenie w regionalnym zróżnicowaniu wartości indeksu starości demograficznej. W obu badanych przekrojach czasowych najwyższy poziom starości poza prowincją Hawana notowały jednostki leżące w centralnej części kraju, takie jak: Villa Clara, Sancti Spíritus, Matanzas czy Mayabeque. Warto również podkreślić, że obszary silnie zurbanizowane charakteryzują się wyższymi wskaźnikami indeksu starości niż obszary wiejskie. Najniższe wartości tego wskaźnika zanotowano na Isla de la Juventud, gdzie zgodnie z jej nazwą (w tłumaczeniu Wyspa Młodości) osiągały one w 2005 r. zaledwie 32,3, podczas gdy średnia wartość dla kraju wyniosła 59,2. Co ciekawe, w 2013 r. nieznacznie niższy ogólny poziom starości demograficznej odnotowano w najbardziej wschodniej prowincji - Guantanamo $(57,1)$, podczas gdy w Isla de la Juventud wynosił on 58,2. Wyspa ta utrzymała jednak palmę pierwszeństwa pod względem najniższych wartości indeksu starości ludności wiejskiej, które wzrosły z 27,6 do 37,5 i były blisko dwukrotnie niższe niż średni krajowy poziom (tab. 3 ).

Nieznacznie niższe wartości wskaźnika starzenia się notowane były we wschodnich prowincjach, co ma związek ze ukazaną wcześniej specyfiką tych obszarów, które ze względu na wiejski i rolniczy charakter, relatywnie niższy poziom rozwoju gospodarczego cechują się wolniejszym procesem starzenia ludności. Niższy poziom wartości wskaźnika starzenia się wynikać może także ze struktury etnicznej tego obszaru, na którym przeważa ludność afrokubańska cechująca się wyższym tempem przyrostu naturalnego oraz niższym saldem migracji zagranicznej. Społeczność afrokubańska wykazuje mniejszą mobilność wewnętrzną, co wynika z uprzedzeń rasowych oraz stygmatyzowania osób pochodzących ze wschodu kraju, nazywanych potocznie palestinos ( „palestyńczycy”). Prowincje wschodniej części kraju cechują się również niższą intensywnością emigracji zagranicznej, co spowalnia odpływ młodszej części populacji. W przypadku terenów wiejskich, które charakteryzują się wyższą stopą urodzeń, wskaźnik starzenia demograficznego jest ogólnie niższy niż na terenach zurbanizowanych, co może mieć pozytywny wpływ na rozwój rolnictwa, które w ostatniej dekadzie jest sektorem szczególnie wspieranym przez rząd (tab. 3).

Badania dynamiki procesu starzenia się ludności Kuby nie pozwalają na jednoznaczne wskazanie przestrzennych różnic czy podobieństw w przebiegu tego procesu. Ogólnie średnia wartość wskaźnika starzenia się demograficznego $\left(\mathrm{W}_{\mathrm{SD}}\right)$ w latach 2005-2013 dla ogółu mieszkańców Kuby wyniosła 4,3, co wskazuje, że proces ten dalej postępuje. Najwyższe wartości odnotowano w przypadku municypium Isla de la Juventud $(6,4)$ oraz w prowincjach Pinar del Rio $(5,9)$ i Guantanamo $(5,1)$. 


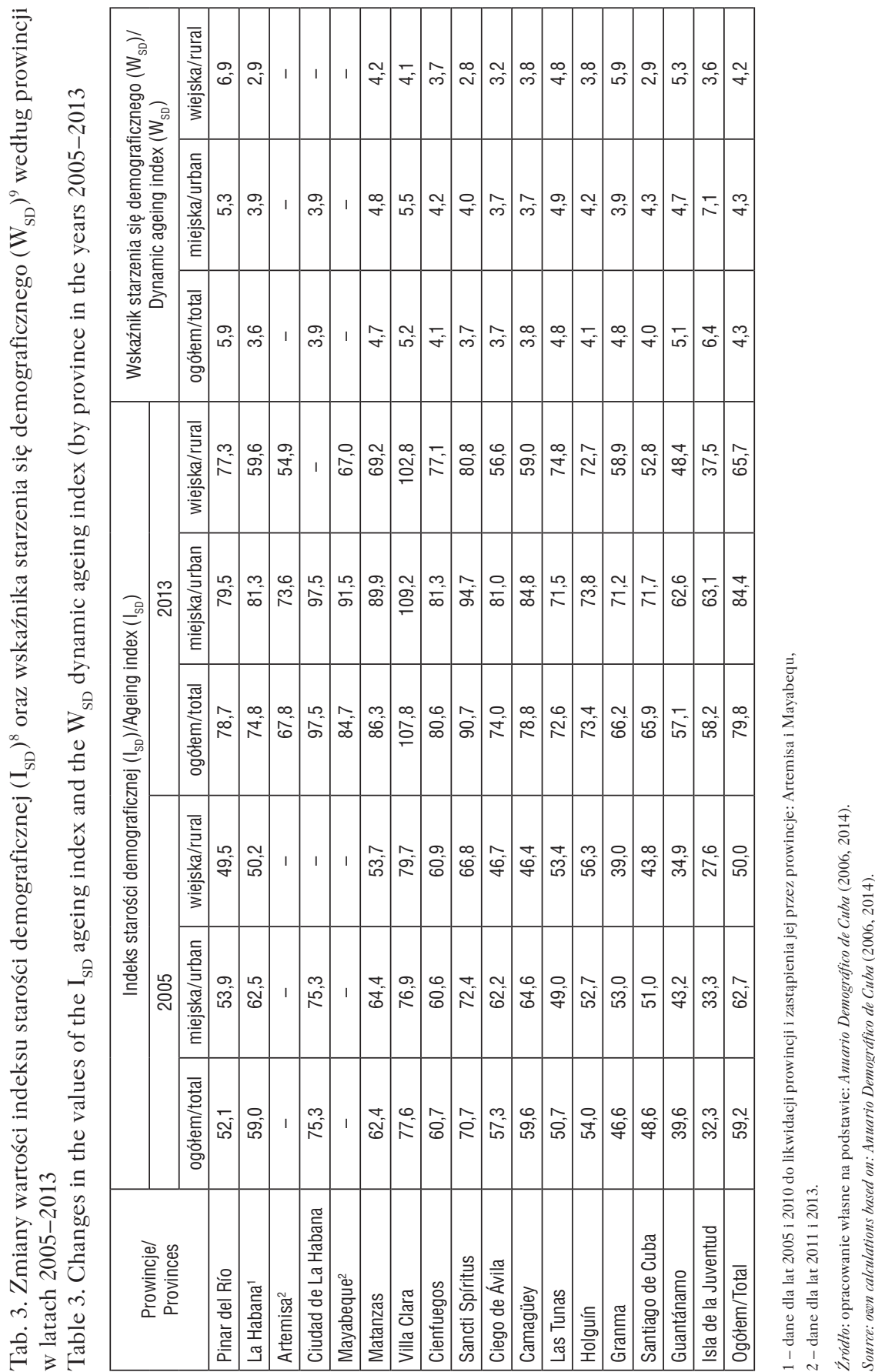


Wspólną cechą tych jednostek był relatywnie niski poziom starości demograficznej na początku badanego okresu. $Z$ jednej strony wiązało się to z ich peryferyjnym położeniem, rolniczym charakterem tych obszarów i niższym poziomem rozwoju społeczno-gospodarczego. $Z$ drugiej zaś strony warto również wspomnieć, że w grupie szybko starzejących się prowincji znalazła się Villa Clara (5,2), która w świetle wartości analizowanego wcześniej indeksu starości cechowała się najwyższym jego poziomem w całym badanym okresie. Nie można więc jednoznacznie wskazać, że prowincje cechujące się niższym poziomem starości demograficznej na początku badanego okresu wykazywały szybsze tempo starzenia się, choć w większości przypadków taka prawidłowość zachodziła. W skali całego kraju różnica pomiędzy tempem starzenia się demograficznego ludności miejskiej i wiejskiej jest niewielka i wskazuje, że społeczności miejskie starzeją się nieco szybciej. Porównując jednak wartości przedmiotowych wskaźników w poszczególnych prowincjach, zauważamy, że tempo starzenia się ludności wiejskiej w większości z nich jest zdecydowanie wolniejsze. Jedynie w prowincjach Pinar del Rio, Granma, Guantanamo i Camagüey szybciej starzała się ludność wiejska (tab. 3 ).

Proces starzenia się ludności w połączeniu z wysokim odpływem migracyjnym z wyspy ma bardzo niekorzystny wpływ na sytuację na rynku pracy i w długofalowej

\footnotetext{
${ }^{8}$ Indeks starości demograficznej $\left(I_{\mathrm{SD}}\right)$, zwany czasami także współczynnikiem obciążenia demogra-
} ficznego, wyraża relację pomiędzy ludnością w wieku 65 lat i więcej a ludnością w wieku 0-14 lat.

$L_{\mathrm{SD}}=\frac{L_{65+}}{L_{0-14}} \cdot 100$

gdzie:

$L_{65+}-$ udział ludności w wieku 65 lat i więcej,

$L_{0-14}-$ udział ludności w wieku 0-14 lat.

W sytuacji gdy udział ludności w wieku 65 lat i więcej przewyższa udział dzieci w wieku 0-14 lat, wartość indeksu starości demograficznej przekracza 100.

Wskaźnik starzenia się demograficznego $\left(\mathrm{W}_{\mathrm{SD}}\right)$ opiera się na punktowych różnicach pomiędzy udziałami ludności młodej i starszej:

$W_{\mathrm{SD}}=[U(0-14) t-U(0-14) t+n]+[U(65+) t+n-U(65+) t]$,

gdzie:

$U(0-14) t$ - udział ludności w wieku 0-14 lat na początku badanego okresu,

$U(0-14) t+n-$ udział ludności w wieku 0-14 lat na końcu badanego okresu,

$U(65+) t$-udział ludności w wieku 65 lat i więcej na początku badanego okresu,

$U(65+) t+n-$ udział ludności w wieku 65 lat i więcej na końcu badanego okresu.

Im wartość tego wskaźnika jest wyższa, tym starzenie się społeczeństwa jest bardziej dynamiczne. Ujemna wartość świadczy o odmładzaniu się populacji (Długosz 1998; Kurek 2008). 
perspektywie może utrudniać reformy kubańskiej gospodarki. Aby przeciwdziałać pogłębiającemu się kryzysowi na rynku pracy, rząd Raula Castro przeprowadził w 2008 r. reformę emerytalną wydłużającą okres aktywności zawodowej. Zakłada ona, że mężczyźni będą mogli przejść na emeryturę po ukończeniu 65. roku życia, a kobiety 60 lat (Strug 2014). Z tego powodu w analizie zmian wartości wskaźnika starzenia się ekonomicznego za ludność w wieku poprodukcyjnym przyjęto grupę wiekową od 65 lat wzwyż. Przestrzenny rozkład wartości wskaźnika starzenia się ekonomicznego wskazuje, że proces ten przebiegał najszybciej w municypium Isla de la Juventud $(19,3)$ i prowincji Pinar del Rio $(17,4)$. W pierwszym przypadku złożyło się na to szczególnie szybkie starzenie się ludności w miastach $(20,1)$, natomiast w drugim głównie za sprawą szybszego starzenia się ekonomicznego ludności wsi $(18,1)$ (tab. 4).

Tab. 4. Zmiany wartości wskaźnika starzenia się ekonomicznego ludności $\left(\mathrm{W}_{\mathrm{SE}}\right)^{10}$ według prowincji w latach 2005-2013

Table 4. Changes in the value of the $\mathrm{W}_{\mathrm{SE}}$ economic ageing index by province in the years 2005-2013

\begin{tabular}{|c|c|c|c|}
\hline \multirow{2}{*}{$\begin{array}{l}\text { Prowincje/ } \\
\text { Provinces }\end{array}$} & \multicolumn{3}{|c|}{ Wskaźnik starzenia się ekonomicznego $\left(\mathrm{W}_{\mathrm{SE}}\right) /$ Economic ageing index $\left(\mathrm{W}_{\mathrm{SE}}\right)$} \\
\hline & ogółem/total & miejska/urban & wiejska/rural \\
\hline Pinar del Río & 52,1 & 53,9 & 49,5 \\
\hline La Habana ${ }^{1}$ & 9,3 & - & - \\
\hline Artemisa $^{2}$ & 3,2 & - & - \\
\hline Ciudad de La Habana & 16,0 & 16,0 & - \\
\hline Mayabeque $^{2}$ & 2,9 & - & - \\
\hline Matanzas & 15,3 & 15,5 & 13,8 \\
\hline Villa Clara & 16,2 & 16,8 & 14,0 \\
\hline Cienfuegos & 17,0 & 17,3 & 15,3 \\
\hline Sancti Spíritus & 15,0 & 15,1 & 14,3 \\
\hline Ciego de Ávila & 14,7 & 15,1 & 12,8 \\
\hline Camagüey & 17,3 & 17,3 & 16,4 \\
\hline Las Tunas & 17,4 & 17,8 & 16,5 \\
\hline Holguín & 16,7 & 17,3 & 15,4 \\
\hline Granma & 16,7 & 15,8 & 17,6 \\
\hline Santiago de Cuba & 15,9 & 16,4 & 14,4 \\
\hline Guantánamo & 16,2 & 16,1 & 15,6 \\
\hline Isla de la Juventud & 19,3 & 20,1 & 16,7 \\
\hline Ogółem/Total & 16,1 & 16,2 & 15,2 \\
\hline
\end{tabular}

1 - wskaźnik wyliczony dla lat 2005-2010,

2 - wskaźnik wyliczony dla lat 2011-2013.

Źródto: opracowanie własne na podstawie: Anuario Demográfico de Cuba (2005, 2013).

Source: own calculations based on: Anuario Demográfico de Cuba (2005 and 2013). 
Poza Isla de la Juventud i Pinar del Rio, wykazującymi najszybsze tempo starzenia się zarówno demograficznego, jak i ekonomicznego na Kubie, w grupie szybko starzejących się ekonomicznie znalazły się także prowincje ze środkowo-wschodniej części wyspy: Las Tunas (17,4), Camagüey (17,3) i Cienfuegos (17,0). Na podkreślenie zasługuje również fakt zdecydowanie wyższego tempa starzenia się ekonomicznego ludności miejskiej w porównaniu z wiejską, jedynie prowincje Pinar del Rio i Granma odbiegają od tego schematu. Jednakże w perspektywie najbliższych lat, po zniesieniu w 2013 r. ograniczeń dotyczących wewnętrznego i zewnętrznego ruchu ludności, najprawdopodobniej zaobserwujemy falę migracji do miast, głównie stolicy i innych ważnych ośrodków, a w konsekwencji skokowy wzrost ludności miejskiej na Kubie. Wzrost mobilności wewnętrznej, a także reformy prawa migracyjnego wprowadzone na początku 2013 r., najprawdopodobniej zmienią obraz przestrzennego zróżnicowania wskaźnika starzenia się demograficznego i ekonomicznego, prowadząc do spowolnienia lub zahamowania tego procesu w miastach oraz jego nasilenia w obszarach wiejskich. Może to doprowadzić do zmiany obecnej sytuacji, w której obszary wiejskie w większości prowincji cechują się niższym poziomem starości oraz wolniejszym tempem starzenia się zarówno demograficznego, jak i ekonomicznego (por. tab. 3 i 4 ).

\section{Wnioski}

Kuba w drugiej połowie XX w., poprzez szerokie spektrum zachowań demograficznych, konsekwentnie podążała ścieżką podobną do państw wysoko rozwiniętych, które dzisiaj zmagają się ze skutkami starzenia się ludności. W skali całego regionu jest jednym z niewielu państw, które znajdują się w zaawansowanej fazie starzenia, obok Urugwaju, Portoryko, Martyniki i Barbadosu (CEPAL 2009).

\footnotetext{
${ }^{10}$ Wskaźnik starzenia się ekonomicznego $\left(W_{\mathrm{SE}}\right)$ wylicza się na podstawie punktowych zmian w ekonomicznych grupach wieku:

$$
\begin{gathered}
W_{\mathrm{SE}}=[P(0-19) t-P(0-19) t+n]+[P(20-44) t-P(20-44) t+n]+[P(45-64) t+n- \\
-P(45-64) t]+[P(65+) t+n-P(65+) t]
\end{gathered}
$$

gdzie:

$P(0-19)$ - udział ludności w wieku przedprodukcyjnym na początku $(t)$ i na końcu $(t+n)$ badanego okresu;

$P(20-44)$ - udział ludności w wieku produkcyjnym mobilnym na początku $(t)$ i na końcu $(t+n)$ badanego okresu;

$P(45-64)$ - udział ludności w wieku produkcyjnym niemobilnym na początku $(t)$ i na końcu $(t+n)$ badanego okresu;

$P(65+)$ - udział ludności w wieku poprodukcyjnym na początku $(t)$ i na końcu $(t+n)$ badanego okresu. Szersze wyjaśnienia na temat interpretacji wartości wskaźnika por. Kurek 2008: 77.
} 
Przeprowadzone badania potwierdzają postawioną hipotezę, że mimo długoletniego wdrażania strategii rozwojowych mających na celu wyeliminowanie przestrzennych różnic w rozwoju społeczno-ekonomicznym, różnice te nadal istnieją i uwidaczniają się w sferze demograficznej. Dowodem na to jest proces starzenia się społeczeństwa kubańskiego, który wprawdzie dotyczy całego obszaru wyspy, ale zarysowują się w nim różnice między wschodnią a zachodnią jej częścią, a przede wszystkim między obszarami miejskimi i wiejskimi. W ogóle obszary wysoko zurbanizowane, o dynamicznie rozwijającej się gospodarce, zarówno w przemyśle, jak i w turystyce, charakteryzują się wyższym poziomem starości demograficznej, ale zarazem niższą bądź średnią dynamiką starzenia się, co potwierdza pierwszą hipotezę szczegółową. Z kolei obszary o zdecydowanie wiejskim charakterze, z niewielką liczbą inwestycji przemysłowych i turystycznych wykazują współcześnie wyższą dynamikę starzenia się ludności, co zakładała druga hipoteza szczegółowa. Dwie prowincje Isla de la Juventud i Pinar del Río są tego najlepszym przykładem. W przypadku pierwszej wynika to z marginalizacji społeczno-ekonomicznej tego terenu i trwałego braku inwestycji. Casus Pinar del Río jest nieco odmienny. Szczególną rolę odgrywa tu struktura gospodarki lokalnej, nastawiona na rozwój rolnictwa, niewielka liczba inwestycji turystycznych, bliskość Hawany i zdecydowana przewaga ludności pochodzenia europejskiego. Czynniki te powodują ogromny odpływ ludności z tych obszarów, zarówno do Hawany, jak i za granicę. Podobną sytuację zaobserwowano także w przypadku prowincji Granma i Guantánamo, gdzie również niewielka liczba inwestycji, rolniczy charakter i niski poziom rozwoju społeczno-gospodarczego powodują odpływ ludności młodej i szybkie starzenie się pozostałej populacji.

Analiza wykazała, że na szybko postępujący proces starzenia się społeczeństwa kubańskiego z jednej strony wpłynęła bardzo niska stopa urodzeń, niska dzietność i powszechność aborcji. Doprowadziły one do gwałtownego spadku ludności w młodych grupach wiekowych, przyspieszając tzw. starzenie się od podstawy piramidy. $Z$ drugiej strony wysoka i ciągle rosnąca przeciętna długość życia przyspieszyła proces starzenia się od wierzchołka piramidy.

Ważnym czynnikiem dynamizującym procesy demograficzne na Kubie jest masowa emigracja zagraniczna, która dodatkowo pogłębia i przyspiesza starzenie się ludności. Od lat 30. XX w., a szczególnie po 1959 r. (po zwycięstwie rewolucji), emigracja zagraniczna była ważnym czynnikiem ubytku ludności głównie w mobilnych grupach wiekowych, co uległo nawet pogłębieniu w ostatnich dwóch dekadach.

Warto również podkreślić, że zjawisku starzenia się ludności Kuby będzie bardzo trudno przeciwdziałać, zważywszy na kryzys gospodarczy, z którym od wielu lat zmaga się kraj, a także przyzwyczajenia społeczeństwa kubańskiego do swobód indywidualnych, umożliwiających kobiecie i mężczyźnie decydowanie o własnych 
planach rodzinnych i prokreacyjnych. Obok wyzwań ogólnokrajowych stoją przed rządem kubańskim również zadania mające na celu niwelowanie znacznych różnic przestrzennych w zjawiskach demograficznych implikujące działania przede wszystkim gospodarcze, które spowodują zmniejszenie odpływu ludności z niektórych prowincji kraju, jak Pinar del Rio, Isla de la Juventud, Granma czy Guantánamo. Są to obszary zmarginalizowane gospodarczo, słabo zurbanizowane, o dominacji sektora rolnego, z których odnotowuje się odpływ ludności w inne regiony kraju oraz za granicę. Jednocześnie badania pokazały, że charakteryzują się one relatywnie niskim wskaźnikiem obciążenia demograficznego w stosunku do reszty kraju, ale wykazują wyższą niż pozostałe prowincje dynamikę starzenia się, co wskazuje, że negatywne procesy demograficzne będą się w nich nasilać. Należy jednak pamiętać, że przestrzenne różnice w procesie starzenia się społeczeństwa w najbliższych latach mogą ulec zasadniczej zmianie, do czego przyczynią się regulacje wewnętrzne dotyczące mobilności ludności, a przede wszystkim nowe inwestycje gospodarcze w rozwój turystyki i sektora rolnego. Konsekwencją tego będzie najprawdopodobniej w pierwszym okresie niwelowanie różnic, a następnie zdecydowany ich wzrost i ostatecznie zmiana przestrzennego obrazu procesu starzenia się.

Kuba obok problemów gospodarczych, którym stawia czoło od dekad, oraz skomplikowanej sytuacji politycznej - zarówno wewnętrznej, jak i międzynarodowej zmaga się także z głębokimi przemianami demograficznymi, które są jeszcze słabo rozpoznane w innych krajach Ameryki Łacińskiej. W związku z tym działania Kuby będzie można uznać za pionierskie w skali regionalnej. Tym bardziej że starzenie się ludności wpływa bezpośrednio na stan gospodarki kraju szczególnie w sytuacji realizowanych współcześnie intensywnych reform ekonomicznych zmierzających do wprowadzenia gospodarki rynkowej oraz ściślejszej współpracy regionalnej. Może się ono stać ważnym ich hamulcem albo elementem wymuszającym trwanie przy rozwiązaniach socjalnych z minionej epoki. Jest to o tyle ważne, że rosnąca populacja seniorów jest grupą społeczną najbardziej zagrożoną niekorzystnymi zmianami ekonomicznymi.

\section{Literatura}

Andrews G.J., Phillips D.R. (red.), 2005, Ageing and Place: Perspectives, Policy, Practice, Routledge, New York.

Anuario Demográfico de Cuba, 2005, 2006, Oficina Nacional de Estadísticas - ONE, Habana. Anuario Demografico de Cuba 2010, 2011, Oficina Nacional de Estadísticas - ONE, Habana. Anuario Demografico de Cuba 2013, 2014, Oficina Nacional de Estadística e Información ONEI, Habana.

Anuario Demografico de Cuba 2014, 2015, Oficina Nacional de Estadística e Información ONEI, Habana. 
Anuario Estadístico de Salud 2014, 2015, Ministerio de Salud Pública, Dirección de Registros Médicos y Estadísticas de Salud, Habana.

Alfonso Fraga J.C., 2006, El descenso de la fecundidad en Cuba. De la Primera a la segunda transición demográfica, Revista Cubana de Salud Pública, 32, 1, http://scielo.sld.cu/scielo. php?script=sci_arttext\&pid=S0864-34662006000100002\&lng=es\&nrm=iso (30.04.2015). Castellón R.H., 1992, El enviejecimiento de la población en Cuba, Estudios Demográficos y Urbanos, 7, 2/3, (20/21), 603-617.

CEPAL, 2009, El envejecimiento y las personas de edad. Indicadores sociodemográficos para América Latina y el Caribe, CEPAL, Santiago de Chile.

Código Penal vigente en las islas de Cuba y Puerto Rico mandado observar por Real Decreto de 23 de mayo de 1879, España, http://bvpb.mcu.es/ es/consulta/registro.cmd?control= BVPB20070014035\&formato=ficha\&aplicar=Aplicar (30.04.2015).

Cotlear D. (red.), 2011, Population aging: Is Latin America ready?, World Bank Publications, New York.

Dembicz A., 1969, Kuba, Państwowe Wydawnictwo Naukowe, Warszawa.

Dembicz K., 2011, Wyspy starości na morzu demograficznym Ameryki Łacińskiej, Studia Ekonomiczne, 95, 11, 219-226.

Dembicz K., 2012, Problemy demografične Kuby przez pryzmat starzenia się ludności, Ameryka Łacińska, 3, 4, 76-83.

Dembicz K., 2013, La actualidad demográfica de Cuba y sus proyecciones hacia el futuro, [w:] K. Dembicz (red.), Cuba: ¿quo vadis?, CESLA UW, Warszawa, Studia i Materiały, $45,57-71$.

Díaz-Briquets S., Pérez L., 1982, Fertility Decline in Cuba: A Socioeconomic Interpretation, Population and Development Review, 8, 3, 513-537.

Długosz Z., 1996, Zró̈́nicowanie struktury wieku na swiecie a metody jej klasyfikacji, Przegląd Geograficzny, 68, 1-2, 151-165.

Długosz Z., 1998, Próba określenia zmian starości demograficznej Polski w ujęciu præestrzennym, GUS-PTS, Wiadomości Statystyczne, 3, 15-25.

Donate-Armada R.A., 2001, The aging of the Cuban population, [w:] Cuba in Transition, 11, Papers and Proceedings of the Eleventh Annual Meeting of The Association for the Study of the Cuban Economy (ASCE), Miami, 481-488, http://www.ascecuba.org/publications/annual-proceedings/cuba-in-transition-volume-11/ (30.04.2015).

Frątczak E., 2002, Proces starzenia się ludności Polski, Studia Demograficzne, 142, 2, 3-28.

Gran Alvarez M.A., Lopez Nistal L.M., 2003, El descenso de la natalidad en cuba, Revista Cubana de Salud Pública, 29, 2, 132-138, http://scielo.sld.cu/scielo.php?script=sci_arttext\&pid=S0864-34662003000200008\&lng=es\&nrm=iso (30.04.2015).

Gran Alvarez M.A., Torres Vidal R.M., Lopez Nistal L.M., Perez Leyva M.E., 2013, Fecundidad, anticoncepción, aborto y mortalidad materna en Cuba, Revista Cubana de Salud Pública, 39, 1, 822-835, http://scieloprueba.sld.cu/ scielo.php?script=sci_arttext\&pid=S0864$-34662013000500003 \& \operatorname{lng}=$ es\&nrm=iso $(30.04 .2015)$. 
Grundy E., 1996, Population ageing in Europe, [w:] D. Coleman (red.), Europe's Population in the 1990s, Oxford University Press, Oxford, 267-295.

Hernández J., Foladori G., 2014, The population dynamic challenge to Cuban socialism, International Journal of Cuban Studies, 6, 1, 25-40.

Hollerbach P.E., 1980, Recent Trends in Fertility, Abortion and Contraception In Cuba, International Family Planning Perspectives, 10. 1, 12-20.

Hollerbach P.E., Díaz-Briquets S., Hill K.H., 1984, Fertility Determinants in Cuba, International Family Planning Perspectives, 6, 3, 97-106.

Iñiguez L., Rojas J., Oliveros A., 2013, Las reconfiguraciones espaciales en la Cuba actual, [w:] K. Dembicz (red.), Cuba: ¿quo vadis?, CESLA UW, Warszawa, Studia i Materiały, $45,39-56$.

van de Kaa D.J., (2003), The idea of a second demographic transition in industrialized countries, The Japanese Journal of Population, 1, 1, www.ipss.go.jp/webj-ad/webjournal.files/population/2003_4/kaa.pdf (25.02.2015).

Kurek S., 2008, Typologia starzenia się ludności Polski w ujęciu præestræennym, Wydawnictwo Naukowe AP, Kraków.

Landstreet Jr. B.F., Mundigo A.I., 1983, Internal migration and changes in urbanization trends in Cuba, Demografia y Economía, 17, 4, 409-447.

Lesthaeghe R., 1991, The second demographic transition in Western countries: An interpretation, IPD Working Papers, 1991-1992, Brussels.

Mayo Abad D., 2002, Algunos aspectos histórico-sociales del aborto, Revista Cubana Obstet Ginecol, vol. 28, no. 2, http://scielo.sld.cu (26.05.2015).

Modrzejewski P., 1987, Præemiany demograficะne ispotecะno-zawodowe ludności Kuby w XX wieku na tle przeobrażen polityczno-gospodarczych Republiki Kuby, Prace Naukowe Uniwersytetu Śląskiego w Katowicach, 848, Wydawnictwo UŚ, Katowice.

Mujeres cubanas en edad fértil. Presencia, niveles de reproducción y muerte materna, 2011, Temas de Estadísticas de Salud, Ministerio de Salud Pública de Cuba, Dirección Nacional de Registros Médicos y Estadítiscas de Salud, Habana.

Okólski M. (red.), 1990, Teoria præejścia demograficznego, PWN, Warszawa.

Okólski M., 2005, Demografia. Podstawowe pojęcia, procesy i teorie w encyklopedycænym zarysie, Wydawnictwo Naukowe Scholar, Warszawa.

Okólski M., Fihel A., 2012, Demografia. Wspótczesne zjawiska i teorie, Wydawnictwo Naukowe Scholar, Warszawa.

Ortiz F., 1973, Contrapunteo cubano del tabaco y el azucar, Ariel, España.

Panorama Territorial. Cuba, 2014, Oficina Nacional de Estadísticas e Información - ONEI, Habana.

Preston S.H., Hime C., Eggers M., 1989, Demographic conditions responsible for population aging, Demography, 26, 4, 691-702.

Sztompka P. (red.), 1999, Impoderabilia wielkiej zmiany. Mentalność, Wartości i więzi spoteczne czasów transformacji, Wydawnictwo Naukowe PWN, Warszawa-Kraków. 
Strug D.L., 2014, Older persons and the Cuban reform process, International Journal of Cuban Studies, 6, 1, 9-24.

Mirostaw Wójtowicz

Uniwersytet Pedagogicwny w Krakowie

Instytut Geografii

ul. Podchorqżych 2, 30-048 Kraków

e-mail:mwojt@up.krakow.pl

Katarzyna Dembicz

Uniwersytet Warswawski

Centrum Studiów Latynoamerykańskich

ul. Smyczkowa 14, 02-678 Warszawa

e-mail:khdembic@uw.edu.pl 